\title{
Islamic Finance and Socially Responsible Investing
}

By Usman Hayat, CFA

Islamic finance and the form of finance generally referred to as "sustainable and responsible investing" (SRI) have yet to actively collaborate with one another. One would think that to strengthen their position in a market dominated by conventional finance, these forms of finance would share their successes and failures and come together for joint ventures to support each other on issues on which they have similar views. But such collaboration has not occurred.

Islamic finance and SRI share some obvious similarities in their objectives (do good; avoid harm), methods (e.g., exclusionary screening), and claims (an emphasis on ethics). Islamic finance and SRI seem to trigger similar expectations among their proponents of being ethically different from conventional finance. They also face similar criticisms of not being able to live up to these expectations, as shown by the form-over-substance debate in Islamic finance and the "green-washing" debate in SRI. Although SRI is older and larger than Islamic finance, which is estimated to have total global assets between US $\$ 1$ trillion and US $\$ 2$ trillion, both are relatively small and growing segments.

Why, then, are Islamic finance and SRI not actively collaborating? Some obvious reasons include their different geographic areas of concentration, differences in target markets, preoccupation with their own growth, perception and reputational concerns, cultural barriers, lack of initiative by industry leaders, and an insufficient understanding of one another. But in the absence of survey data, it is difficult to pinpoint the exact reasons for this lack of collaboration.

Islamic finance is practiced by international financial institutions offering conventional finance. Islamic finance has also drawn increasing interest from other international organizations, such as the World Bank, which organizes an annual conference with the Islamic finance standard setter, the Accounting and Auditing Organization for Islamic Financial Institutions (AAOIFI). Similarly, many conventional financial institutions are active in SRI. For instance, Goldman Sachs has participated in the first social-impact bond in the United States and has launched its 10,000 Women and 10,000 Small Businesses initiatives, and its asset management arm is a signatory to the UN Principles for Responsible Investment. If both Islamic finance and SRI can work with the leading (and sometimes controversial) faces of conventional finance, why can't they work with each other?

Some financial products do meet criteria for both traditional Islamic and modern environmental, social, and governance (ESG) investing. For instance, the Sustainable Resources Fund invests in a mix of agro-forestry, land, and sustainable agricultural sectors that is designed to appeal to Islamic and "green" investors. In 2012, Australian solar companies secured funding through green sukuk for projects in Indonesia. In 2006, the Dow Jones Islamic Sustainability Index was introduced. Nonetheless, such examples remain exceptions.

The general lack of interaction between Islamic finance and SRI can also be observed in professional education. For instance, the curricula for the Sustainable Investment Professional Certificate (offered by the John Molson School of Business at Concordia University) and the Islamic Finance Qualification (offered by the Chartered Institute for Securities \& Investment) have limited, if any, shared content.

The same trend is observed in industry reports, even in the United Kingdom, which is home to both SRI and Islamic finance. For instance, the TheCityUK's 2012 report on Islamic finance does not address other forms of ethical finance, and the 2011-12 U.K. Sustainable Investment and Finance Association annual review does not discuss Islamic finance. Unsurprisingly, this lack of interaction is also apparent in industry conferences on the topics of Islamic finance and SRI.

Of course, there are differences between Islamic finance and SRI. One significant difference is that the concerns of Islamic finance go beyond the purpose of financing and also cover the structure of financing-for example, the Islamic prohibitions against riba and excessive gharar, which are generally interpreted to include lending money on interest and the trading of risk. Additionally, the exclusionary screening applied in Islamic finance goes beyond the usual suspects (e.g., alcohol, tobacco, and gambling) and covers some conventional financial services because of the prohibition against riba. But the current form-oriented and legalistic compliance in Islamic finance often has little effect on the economic substance of transactions, implying that these prohibitions cannot explain the lack of collaboration with SRI.

While Islamic finance and SRI may continue to grow without active collaboration, one event that will bring together experts from both sides is the CFA Institute Middle East Investment Conference in Dubai, United Arab Emirates, on 20-21 March 2013. Ibrahim Warde, professor of international business at Tufts University, will be sharing his analysis of Islamic finance in the global economy, and Harry Hummels, professor of ethics, organizations, and society at Maastricht University and managing director of SNS Impact Investing, will discuss impact investing. One question we would certainly like them to address is how Islamic finance and SRI can actively collaborate in the future.

Usman Hayat, CFA, is director of Islamic Finance and ESG at CFA Institute. 